\title{
Sociocultural Aspects of Russian-speaking Parents' Choice of Language of Instruction for their Children in Estonia
}

\author{
Raija Pini Kemppainen \\ raija_kemppainen@byu.edu \\ Scott Ellis Ferrin \\ Steven J. Hite \\ steve_hite@byu.edu \\ Sterling C. Hilton
}

Follow this and additional works at: https://scholarsarchive.byu.edu/facpub

Part of the Educational Leadership Commons

\section{Original Publication Citation}

Kemppainen, R., Ferrin, S.E., Hite, S.J., \& Hilton, S.C. (28). Sociocultural aspects of Russianspeaking parents' choice of language of instruction for their children in Estonia. Comparative Education Review, 52(1), 93-119. http://www.jstor.org/stable/1.186/52443

\section{BYU ScholarsArchive Citation}

Kemppainen, Raija Pini; Ferrin, Scott Ellis; Hite, Steven J.; and Hilton, Sterling C., "Sociocultural Aspects of Russian-speaking Parents' Choice of Language of Instruction for their Children in Estonia" (2008). Faculty Publications. 209.

https://scholarsarchive.byu.edu/facpub/209

This Peer-Reviewed Article is brought to you for free and open access by BYU ScholarsArchive. It has been accepted for inclusion in Faculty Publications by an authorized administrator of BYU ScholarsArchive. For more information, please contact ellen_amatangelo@byu.edu. 


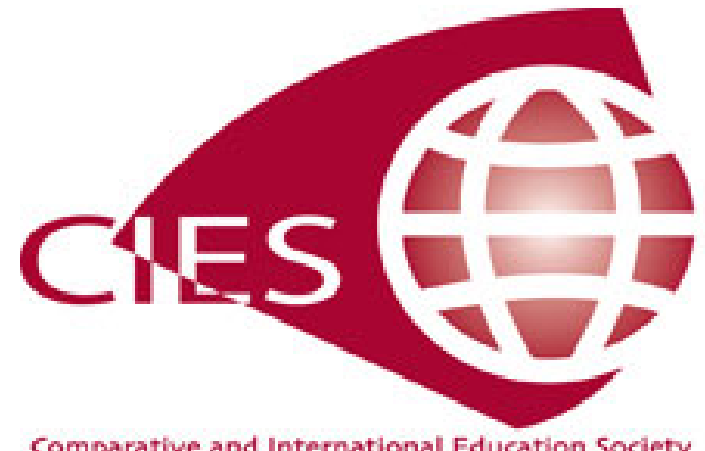

Sociocultural Aspects of Russian-Speaking Parents' Choice of Language of Instruction for Their Children in Estonia

Author(s): Raija Pini Kemppainen, Scott Ellis Ferrin, Steven J. Hite, Sterling C. Hilton Reviewed work(s):

Source: Comparative Education Review, Vol. 52, No. 1 (February 2008), pp. 93-119

Published by: The University of Chicago Press on behalf of the Comparative and International Education

Society

Stable URL: http://www.jstor.org/stable/10.1086/524307

Accessed: 07/03/2012 16:49

Your use of the JSTOR archive indicates your acceptance of the Terms \& Conditions of Use, available at http://www.jstor.org/page/info/about/policies/terms.jsp

JSTOR is a not-for-profit service that helps scholars, researchers, and students discover, use, and build upon a wide range of content in a trusted digital archive. We use information technology and tools to increase productivity and facilitate new forms of scholarship. For more information about JSTOR, please contact support@ jstor.org.

The University of Chicago Press and Comparative and International Education Society are collaborating with JSTOR to digitize, preserve and extend access to Comparative Education Review. 


\title{
Sociocultural Aspects of Russian-Speaking Parents' Choice of Language of Instruction for Their Children in Estonia
}

\author{
RAIJA PINI KEMPPAINEN, SCOTT ELLIS FERRIN, STEVEN J. HITE, \\ AND STERLING C. HILTON
}

In most cases, parents whose native language is not predominant in the area they live in have no opportunity to choose the language for their children's instruction in schools. However, in some areas language minority families have options regarding the language of instruction (e.g., Finns in Sweden and Russians in Estonia). This article focuses on language choice from the viewpoint of these families. Typically, discussions of language of instruction have focused on integrative issues, such as creating loyal citizens, or instrumental or practical issues, such as education or labor market opportunities (Mets 2004). Choice, however, may have deeper cultural and emotional meanings for families, and such meanings may need to be considered by policy makers.

In the United States, for example, policy debates on language of instruction have largely focused on whether or not to employ bilingual education strategies. In fact, states such as California, Arizona, and Massachusetts have forbidden (via referenda) the use of bilingual education, mandating English immersion, with approximately a year of transition in limited instances. Consequently, research in this area has become so politicized that, when a panel of scholars from the National Research Council studied the issue and found a positive effect from bilingual education, an opponent of bilingual education wrote that the report of the panel was intended to convey that "there is no evidence that there will be long-term advantages or disadvantages to teaching limited-English students in the native language" (Glenn 1997, 66). The study directors themselves had stated to the contrary: "Empirical results . . . support the theory underlying native language instruction" (August and Hakuta 1997, 147). Similarly, a recent meta-analytical study regarding the effectiveness of bilingual versus monolingual educational methods conducted by a panel of researchers appointed by the Bush administration found small to modest gains from bilingual programs. However, the Bush administration, after seeing the findings, declined to release the report (Krashen and McField 2005).

In such a highly charged policy climate in the United States, most parents do not have a choice in the language of instruction for their children's schooling. The U.S. language policy clearly is limiting families' language

Electronically published January 9, 2008

Comparative Education Review, vol. 52, no. 1.

(c) 2008 by the Comparative and International Education Society. All rights reserved.

0010-4086/2008/5201-0002\$10.00

Comparative Education Review 
choices, whereas some immigrant-receiving countries have disregarded immigrant policies in other respects.

Despite its 5 million Turks, Germany tends to deny being an immigrant country (Beck 2003). ${ }^{1}$ Turkish immigrants are generally perceived as temporary migrant workers, a view that might be connected with the lack of a comprehensive immigration and naturalization policy. Immigrant families in Germany tend to lack educational support, despite evidence (e.g., from the Programme for International Student Assessment study) that their immigration and socioeconomic challenges cause immigrant children on average to have lower academic performance than the majority student population (Beck 2003; Hebenstreit-Müller 2003). German schools typically focus solely on German as the language of instruction. Bilingual education has not been given sufficient consideration in Germany, despite evidence of the long-term positive effects of bilingualism on linguistic and academic development as indicated in international research. Consequently, the language issue in German schools is treated as a transitional problem (Gogolin 2003).

In contrast, education policies in some countries emphasize the significance of students' first language. Many of these countries allow parents from "large" minority groups to choose whether to have their children instructed in their own or in the majority group's language. For example, in Sweden, the Finns, a historic and immigration-based population, may have their children taught bilingually or in their native language. ${ }^{2}$ In bilingual classrooms for Finnish students in Sweden, half (at most) of the instruction occurs in the child's first language. In friskolor (Finnish free schools), the language principle is the same as in bilingual schools: instruction is provided in Finnish and Swedish (Tuomela 2001). The goal in Sweden is to assure the active bilingualism of all immigrant children. Swedish municipalities are obligated to organize instruction in the first language ( 2 hours weekly) for schools in which there are at least five children of the same language background (Tuomela 2001).

Likewise, in Finland, the goal is to provide functional bilingualism for immigrant students (e.g., Russians, Estonians, Somalis) through the use of Finnish as a second language and through 2 hours of instruction per week in the first language (Opetushallitus 2004). In addition, Finland is officially a bilingual country (Finnish and Swedish), and the Swedish-speaking pop-

\footnotetext{
${ }^{1}$ However, in recent years there has been a movement at the national political level about this previously ignored area of policy (Beck 2003). Although easy access to German citizenship for Turkish immigrants has long been unresolved (Joppke 1996), the naturalization rate is increasing. In 1990 only 1 percent of the Turks in Germany had German citizenship, whereas by 1999 the figure had risen to 17.5 percent (Østergaard-Nielsen 2003). Citizenship requires 8 years of residence and 5 years of employment in Germany and knowledge of German language and history. Since 2001, children born to immigrant parents in Germany with one of the parents having an unlimited permission of residence automatically receive German citizenship.

${ }^{2}$ Reinforcing this language-of-instruction policy, the Finnish language was officially recognized as a national minority language in Sweden in 2000, providing language protection (Lainio 2001).
} 
ulation has broad language rights, including, for example, the availability of education in Swedish from preschool to university levels.

The status of the Swedish language in education in Finland is somewhat similar to the status of the Russian language in education in Estonia. Both minority languages (Swedish in Finland and Russian in Estonia) used to be dominant languages in the countries. Until the nineteenth century Finland was a part of Sweden; thus Swedish speakers are not considered an immigrantbased population. The Russian-speaking population in Estonia entered the country during the Russian occupation after World War II (Rannut 2004b), largely between the 1940s and 1980s (Vetik 1993).

The present research was undertaken to identify sociocultural variables that influence whether Russian-speaking parents living in Estonia choose Russian, Estonian, or bilingual (Russian and Estonian) instruction for their children. The sociocultural situation of Russian speakers in Estonia is particularly interesting because Russian was the lingua franca in the Soviet Republic of Estonia but has become a foreign language in independent Estonia. Notably, Russian speakers have broad opportunities to use their language in Estonian society, with access to Russian-language services in the private service sector, media, and culture (Issakov 1999). There is also a vast and proximate reservoir of Russian speakers surrounding Estonia. Additionally, although Russian speakers have somewhat lower workplace salaries (Titma et al. 1998), their level of educational attainment equals that of Estonian speakers (Pavelson 2000).

Although both the Turkish- and Russian-language minorities formed during roughly the same era, the situation of the Turkish population in Germany is quite different from Russian speakers in Estonia. For instance, Turks in Germany have limited access to local news in the Turkish language, though they can easily access satellite channels and print news media from Turkey (Østergaard-Nielsen 2003) that cover news stories in European countries such as Germany. Moreover, compared to the German average, Turkish immigrants are more often in the lowest category of the EGP (Erikson, Goldthorpe, Portocarero) class scheme. While 14 percent of Germans belong to the lowest social class, as many as 80 percent of Turks who immigrated to Germany as adults are in this class (Kalter and Granato 2002). In addition, unemployment among Turkish youth in Germany is high, and a disproportionately high number of Turkish students leave school without qualifications (Beck 2003; Østergaard-Nielsen 2003).

\section{Background}

After centuries of rule by neighboring countries, Estonia became independent in 1918. During its short period of independence, Estonian culture and economy progressed rapidly. However, the Second World War interrupted this progress, and the country was occupied first by the Soviet Union and then by Nazi Germany. At the end of the war Estonia was annexed to 
the Soviet Union and remained a part of the USSR until 1991. During the annexation years there was a massive immigration of Russian speakers from Russia and other Soviet republics to Estonia, due both to colonizing policy and to Estonia's relatively higher standard of living (Kionka and Vetik 1996).

Although some have referred to the Russians in Estonia as a "colonial minority" (Kirch et al. 1997), those who have entered Estonia from other countries are classified as immigrants according to criteria of international law (Capotorti 1977). In the 1989 census, those who were foreign born (including their children) made up 36 percent of the whole population (ESA, as cited in Katus et al. 1998), which means that nearly all those not of Estonian descent (comprising 38.5 percent of the country's residents) are first- or second-generation immigrants (Kirch 1999). Russian speakers, along with Belarusians and Ukrainians, who mostly are assimilated with the Russians in Estonia, represent about one-third of the population in Estonia (Kirch 1999).

During the Soviet era, many Estonian institutions-such as banks, statistical bureaus, the militia (Russian police), transportation systems, and industrial production-functioned in the Russian language (Rannut 1991). A Russian-language school network was established to serve Russian-speaking children, while Estonian-speaking children attended Estonian schools (Estonian Ministry of Education 1997). Education from preschool to university was provided in the native language for the main populations in Estonia, in contrast to education in the other Soviet republics, which was mostly in Russian. ${ }^{3}$ However, Estonian schools were required to teach Russian as a second "native language" (Rannut and Rannut 1995), and the curricula in Russian-language schools included some practical Estonian as a second language. The emphasis on the Russian language created one-way bilingualism: Estonians were expected to learn the Russian language, while only a small percentage of Russians learned Estonian.

The linguistic situation changed after Estonia regained its independence in the fall of 1991. Estonia reformulated the status of Russians by language legislation: Estonian became the national language, and Russian became a foreign language (Rannut 2001, 2004a). In addition, most nonnative Estonians (over 250,000 people) became noncitizens based on new citizenship policies. A large number of them took Estonian citizenship, but many others chose Russian citizenship. Estonian citizenship required 5 years of residence (Smith et al. 1998) as well as knowledge and skill in the Estonian languagelistening comprehension, reading and summarizing, conversational speaking, and simple writing (Rannut 2001). Since the early years of independence, the number of Estonian citizens has risen constantly. Further, the share of non-Estonians with ability to speak Estonian has increased from 14 percent in 1988 to 37 percent in 2000 (Rannut 2004a). According to the 2000 census,

${ }^{3}$ Juri Valge, personal communication, September 21, 2000. 
about 40 percent of the Russians living in Estonia had Estonian citizenship, while 37 percent remained "undefined" (ESA Statistikaamet 2005).

Changes in language and citizenship policies and practice posed major challenges for Russian speakers in Estonia (Vihalemm and Lauristin 1999). An estimated 100,000 Russian speakers emigrated to other parts of the former Soviet Union during the 1990s (Issakov 1999; Vetik 1999), with the factors for emigration being, along with the withdrawal of the Russian military, changes in the social and economic environments and a surge in national identity, especially among Belorusians and Ukrainians (Rannut 2004a). The new language and citizenship policies aroused criticism among non-Estonians (Vallens 1995). However, resistance toward the citizenship and language polices has declined, and some scholars characterize the remaining Russian speakers in Estonia as socioeconomic immigrants with no significant interest in political agendas nor involvement in political mobilization (Smith 1998; Ozolins 2000). Nevertheless, the unrest in Tallinn in May 2007 concerning the removal of a statue commemorating Soviet soldiers suggests that political tensions may exist beneath the surface.

Estonian policies regarding the Russian-speaking population gained political attention elsewhere in Europe after independence. For example, Russia accused Estonia of human rights violations. Although the human rights commissions found no violations, in order to gain membership Estonia had to comply with the recommendations from the European Union in its language policy development (Ozolins 2000). Language policy requests by the Organization for Security and Co-operation in Europe were incorporated into the Estonian language law, softening the language requirements set for immigrants. For example, the use of the Russian language has been expanded in several domains, such as the service sector (Mets 2004).

Differing from language policies for other sectors, public education has continuously designated both Russian and Estonian as official languages of instruction, at least at the basic education level. About 70 percent of Russian children still attend Russian-language schools at all grade levels (Language Immersion Centre 2006a). The academic level of these schools compares well with that of the Estonian-language schools (Riiklik eksami-ja kvalifikatsioonikeskus 2006).

The Law of Basic and Secondary Education passed in 1993 and amended in 1997 required that the language of instruction at the secondary level, grades 10-12, in state and municipal Russian-language schools shift from Russian to Estonian by 2007 (Rannut 2001). However, according to the Ministry of Education, there are no plans to eliminate Russian instruction in Russian-language basic schools, grades 1-9. ${ }^{4}$ Although some Russian-language schools have been able to prepare their students for the shift of language of

\footnotetext{
${ }^{4}$ Likewise, Latvia and Lithuania retained education for the native population in their native languages, Latvian and Lithuanian, during the Soviet era.
} 
instruction, the Estonian parliament has granted an extension for the shift (Mets 2004). The greatest obstacle for the shift is in preparing Russian-speaking teachers to teach in Estonian (Mets 2004). ${ }^{5}$ Some politicians have viewed the future of Russian high schools as a major unsolved language policy issue in Estonia (Mets 2004).

Recent research indicates that one-third of Russian public school students in Estonia have no interest in studying the Estonian language (Kunnas 2004). In contrast, many Russian-speaking families want to guarantee acquisition of the Estonian language for their children, and they seek out language alternatives in education. These families typically send their children to Estonianlanguage schools. This trend became more common in the mid-1990s after the Law of Basic and Secondary Education was passed (Kemppainen and Ferrin 2002); by 2001 approximately 5 percent of Russian children studied in Estonian-speaking schools (Rannut 2001).

Generally, Russian students in Estonia are encouraged to enter Estonian schools, particularly preschools. Granting access to Estonian-language schools is a school-level decision, depending on the interest of the school. Some Estonian schools, particularly the most desirable ones, may have language requirements that potentially limit access by non-Estonian-speaking youth. ${ }^{6}$ However, with the declining student population in Estonia, there is competition over students, which may cause schools to admit students with poor Estonian-language skills. In areas where the Russian population density is low and the number of Russian-language schools is limited, it is common for Russian speakers to attend Estonian-language schools. ${ }^{7}$

Yet another language option for Russian-speaking students in Estonia is to enter an immersion program, a bilingual program in which a child's first and second languages are both used for instruction. Immersion programs are administered under the Language Immersion Centre (2006b). The students in these programs are not expected to have previous knowledge of Estonian; in fact, program administrators anticipate that Estonian will not be one of the students' home languages. According to Larissa Vassiltshenko and colleagues (1998), non-Estonian-speaking parents prefer bilingual basic education in grades 1-9, as indicated by program expansion. In 2001 there were seven early immersion programs in Estonia, but by 2003-4 there were 12 early immersion programs and 20 late immersion programs (Language Immersion Centre 2006c). Currently, 2,552 students are enrolled in these programs (Language Immersion Centre 2006a), constituting 25 percent of the non-Estonian student population. ${ }^{8}$

\footnotetext{
${ }^{5}$ In contrast, a similar shift in Latvia occurred as planned in 2004 (Kunnas 2004; Radzevich 2004).

${ }^{6}$ Ülle Rannut, personal communication, August 22, 2005.

${ }^{7}$ Marje Pavelson, personal communication, September 18, 2000. In this research, elite schools were excluded from sampling.

${ }^{8}$ Mart Rannut, personal communication, July 25, 2006.
} 
Variables Associated with Choice of Language of Instruction

Parents' choice of language of instruction for their children is a complex phenomenon. Such choice needs to be examined in political, demographic, and social contexts, and decisions may involve several variables. Relevant variables include sociocultural variables, such as language attitudes; pedagogical variables, such as parental assumptions regarding second-language acquisition; linguistic variables, such as children's level of second-language proficiency; family-related variables, such as socioeconomic status; and schoolrelated variables, such as quality of education or distance to school. Because of the wide range of potential variables associated with the choice of language of instruction, this investigation is limited to sociocultural variables, emphasizing social and cultural relations and perceptions of these relations between the majority and minority language speakers.

Literature concerning parental choice of language of instruction and factors related to that choice is limited. Robert Gardner and Wallace Lambert's (1972) classic work on motivation to learn a language refers to instrumental motives, such as gaining educational and job opportunities, and integrative reasons, which pertain to gaining citizenship and integrating into the host society. Gardner and Lambert's theory is based on the assumption that learning the second or foreign language is desirable socially or is possibly the only acceptable language behavior politically or economically. However, when language choice is available, such as choice of a first language as language of educational instruction, a cultural motivation may exist, such as the desire to maintain separation of the native culture, seemingly a reverse of integrative motivation. For example, research in Canada among French-speaking parents demonstrated that some parents sent their children to Frenchlanguage schools to maintain their ethnic identity, culture, and language-to remain within their minority group heritage (Landy and Allard 1985). ${ }^{9}$

The variables included in the present study were identified based on John Schumann's $(1978,1986)$ acculturation model and the findings of an associated qualitative study (Kemppainen et al. 2004). The findings of Kemppainen and colleagues reinforce Schumann's work, stressing the importance of the following sociocultural variables: social dominance, enclosure, integration strategy, length of residence, congruence or similarity of cultures, and intergroup attitudes. ${ }^{10}$

Social dominance refers to political, technical, or cultural superiority. If

\footnotetext{
${ }^{9}$ Earlier research in Estonia investigating school language choice examined language program options and parental preferences but did not seek to explain these preferences in relation to sociocultural or other factors (see, e.g., Vassiltshenko et al. 1998; Vihalemm 1998).

${ }^{10}$ Schumann adds the following variables as well: the size of the language group and its cohesiveness. The sample was drawn from communities with different sizes of Russian population to achieve variation in the sample; however, because the selection focused on schools with different language programs in given communities, the data do not allow the choice of school language in these different communities to be compared. Cohesiveness was not investigated in this research.
} 
speakers of the national language have social dominance, the resulting social distance may hinder minority language speakers from learning the national or target language. Conversely, when the speakers of the smaller language group (e.g., a colonial group) are socially dominant, people in the smaller language group do not tend to learn the majority language. During the Soviet era, some Russian speakers (e.g., scientists, party members, and military officers) formed an elite group along with the Estonian-speaking upper class. The Russians in Estonia at this time had social dominance, with "Russification" policies influencing linguistic practice (Rannut 1991); thus Russians had little need to learn Estonian. After Estonian independence, Russian became a foreign language, and many Russian speakers lost their citizenship status. These changes in the political and linguistic situation likely affected social dominance in Estonia, which may have influenced language of instruction choice. When Russian parents perceive greater dominance by Estonian speakers, they are predicted to choose Russian language instruction, while perceiving social equality is expected to be associated with choosing Estonian language instruction for their children.

Enclosure refers to the degree to which the groups share social institutions (Schumann 1978, 1986). Low social enclosure (groups contacting frequently rather than remaining enclosed as units) may enhance second-language learning. Traditionally Russians and Estonians have had high enclosureseparate communities and institutions-and Russian-speaking social and cultural institutions continue to exist. Segregation of Russian speakers and Estonian speakers is still high, as evidenced by different housing areas, work places, cultural habits, and marriage partners (Rannut 2004a). This situation is a predictor of low second-language learning and, by extension, of low preference by Russian-speaking parents for Estonian or bilingual programs, whereas Russian-speaking respondents who have more contact with Estonianspeaking people are expected to favor Estonian and bilingual options.

Integration strategy differentiates members of the minority language groups who do not assimilate into the majority culture, those who do assimilate but preserve their own culture, and those who fully acculturate and abandon much of their minority culture. According to some research, only a very small percentage of Russian speakers are willing to fully assimilate into Estonian culture (Laitin 1996), but many Russian speakers are adapting to the reality of the language requirements, as indicated in increased Estonian-language acquisition (Pettai and Proos 1999; Rannut 2004a) and increased Estonian citizenship (ESA Statistikaamet 2005). Thus, it is anticipated that Russian parents who perceive themselves as more integrated into Estonian culture are more likely to choose to send their children to Estonian language or bilingual schools.

Additionally, Russian-speaking parents' intended length of residence is expected to be positively associated with interest in choosing Estonian-language 
schools. And, extrapolating from Schumann's (1978, 1986) notion that second-language learning is facilitated by the extent of congruence between the majority and minority group cultures, it could be predicted that Russianspeaking parents who perceive greater similarity in the two cultures would tend to choose Estonian schools. Also, intergroup attitudes are associated with second-language acquisition (Schumann 1978, 1986), and, according to Kemppainen and colleagues (2004), attitudes toward the first and second language and native and majority culture are expected to be associated with choice of language of instruction. Ülle Rannut's (2005) research that further tested some of the findings of Kemppainen and colleagues emphasized the importance of attitudes toward the second language when choosing education in that language for one's children. Russian-speaking parents with more positive attitudes toward Estonian language and culture are expected to choose Estonian-language schools. Finally, Russian-speaking parents who have at least some Estonian ethnic background and who identify themselves as Estonian are anticipated to be more likely to select Estonian language education for their children (Kemppainen et al. 2004).

In summary, the sociocultural variables adopted for this research were social dominance, enclosure, citizenship and second-language proficiency (integration strategies), length of residence, attitudes toward the first language, attitudes toward the second language, attitudes toward the native culture, cultural congruence (attitudes toward the majority culture), ethnic background, and ethnic identity. Figure 1 presents a model of the sociocultural variables and interactions that were initially hypothesized to affect parents' choice of language of instruction.

\section{Method}

To examine which sociocultural variables are related to parents' choice of language of instruction, 346 Russian-speaking parents in three towns in Estonia were surveyed. Using a cross-sectional survey design, researchers collected data during the fall of 2001 in Estonia. Follow-up research conducted by Ülle Rannut (2005) tested further some of the findings of this study.

\section{Sample}

Because a large majority (91 percent) of Russian speakers lives in urban areas (Rannut 2004a), the sample was designed to represent the urban population of Russian-speaking parents with children currently in Estonian public schools. Three towns reflecting differences in Russian concentration and socioeconomic status were chosen (Fowler 1993; Neuman 1994). Narva, Tallinn, and Tartu are, respectively, 92 percent, 47 percent, and 16 percent Russian speaking (Veidemann 1999). ${ }^{11}$ Tallinn has the highest socioeconomic

${ }^{11}$ Mart Rannut, personal communication, September 30, 2001. 


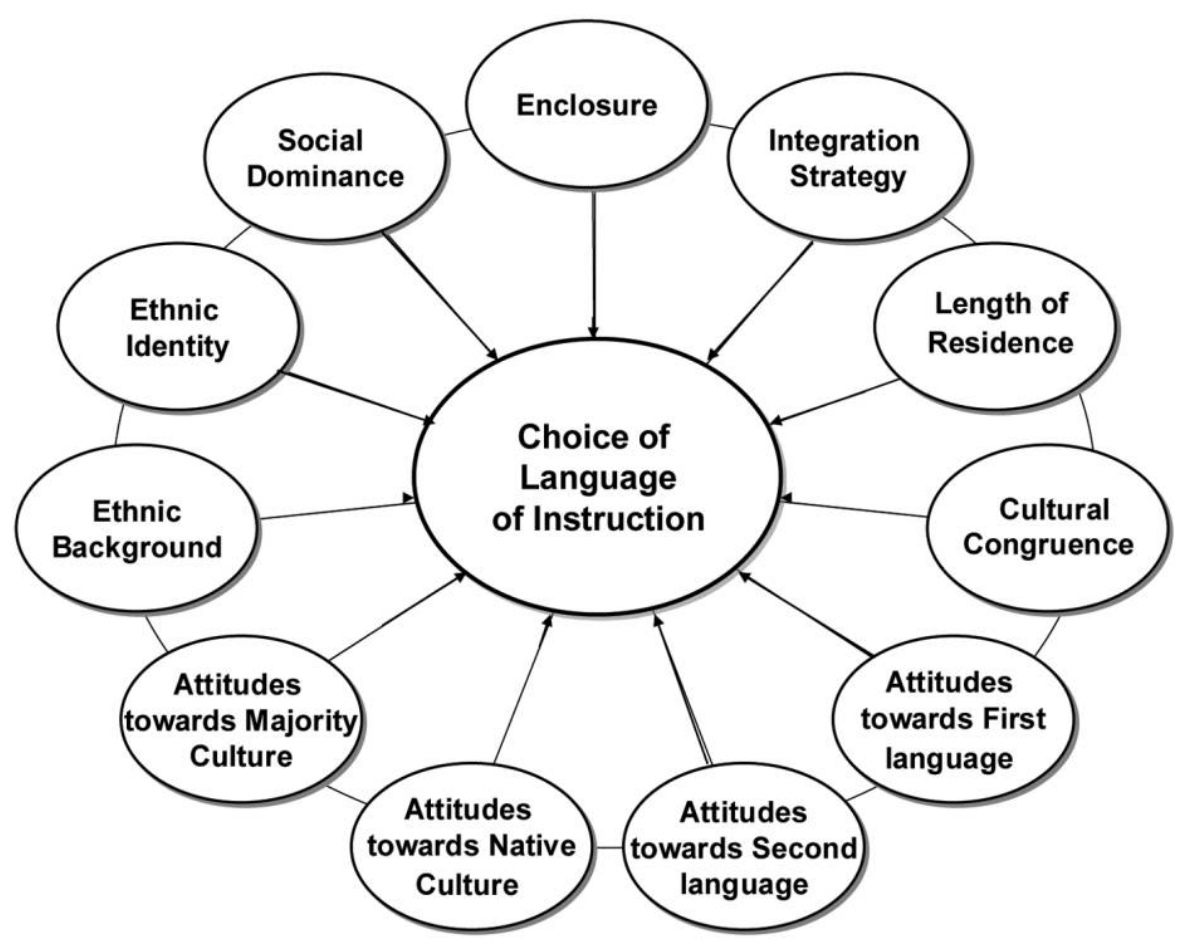

FIG. 1.-Initial sociocultural variables associated with choice of language of instruction

level in all of Estonia, measured in per capita income, including salary and other sources of income, while Narva has the lowest socioeconomic level of the three selected towns (Vihalemm 1997). Additionally, most (81 percent) Russian-language schools in Estonia are situated in Tallinn and surrounding areas and in northeast Estonia, including the city of Narva and surrounding counties, and in Tartu (Kirch 2001). To the extent that these three towns represent diverse urban settings in Estonia, the results may be carefully generalized to Russian speakers in Estonia.

In each town, sampling for research subjects occurred in two stages. First, school types were purposefully selected to ensure that the main language options for Russian-speaking students (Russian, Estonian, and bilingual) were represented. The individual schools were identified using probability sampling through a randomized list of the different school types in each town. ${ }^{12}$

${ }^{12}$ For practical reasons, two randomly selected Russian-language schools were replaced by not randomly selected cases because of insufficient information regarding schools. In Tallinn the randomly selected Russian school had a gümnasium with adult learners, and therefore only the fifth-grade level was available in the school for this research, and the sample of gümnasium students was replaced. The gümnasium-level students were selected from the same Russian school that was identified for researching students in bilingual programs. In Tartu, a school with a Russian name was identified, but despite the name it turned out to be an Estonian school. There were only a few Russian schools available, and, because these schools did not differ significantly from one another, one of them was selected. The two 
To survey only schools with the typical choice situation, elite schools with restricted admissions were dropped from the sampling list. Second, students in the randomly selected schools were sampled to determine which parents were to be surveyed. Parents of students in eleven schools were surveyed, including three schools each in Narva and Tartu and five schools in Tallinn.

Initially, three age groups were chosen: fifth- and eleventh-grade students in Estonian- and Russian-speaking schools, in order to give variance in parental perceptions, and second-grade students in bilingual programs, since at the time of data collection second graders were the oldest age group in most of these new programs. However, because there were few Russian students in Estonian-language schools in Tallinn and Tartu, all grades were included in the sample. In the Narva Estonian school, the only Estonianlanguage school in the town, the fifth and sixth graders and the whole gümnasium level (grades 10-12) were included. ${ }^{13}$ In Russian schools with several classes in the same level, the school administrators selected the classes to be included. It appears that the parents selected for the research had a real opportunity to choose the school and language for their children. The parents did not indicate anywhere (e.g., in open comments, inquiring about reasons for choice) that the choice would be impacted by limited access to school.

\section{Measurement and Data Collection}

The questionnaire was designed to measure the 11 sociocultural variables predicted to be related to parental choice of language of instruction: ${ }^{14}$

- Social dominance (measured as self-perceptions of superiority/equality/inferiority of minority [first] language speakers vis-à-vis majority [second] language speakers)

- Enclosure (measured as contact/wish for contact with the second language speakers on a scale of four levels )

- Integration strategies (measured as citizenship-Russian, Estonian, other-and second-language proficiency on a scale of five levels)

- Length of residence (measured in years)

- Attitudes toward the first language (measured as perceived importance of the first language in future society in a ranking order from one to

schools replacing the randomly selected schools are similar to the schools in each town and do not have distinctive characteristics that would affect the outcome of the research, according to an Estonian informant (Mart Rannut, personal communication, February 24, 2003).

${ }^{13}$ The age ranges of students in the Russian and Estonian schools were similar, and the perspectives of these parents should compare well. However, the students in the bilingual programs were younger, a fact that might bias the comparison between the bilingual schools and the other language programs, as parents of younger parents may differ in their other demographic characteristics, attitudes, and even factors for school program selection.

${ }^{14}$ The questionnaire was translated from English to Russian and back translated by a native Russian speaker to English for lexicon equivalence before the final version was completed (Neuman 1994). 
five)

- Attitudes toward the second language (measured as perceived value of the second language on a scale of four levels)

- Attitudes toward the native culture (measured as perceived importance of maintaining native culture on a scale of four levels)

- Attitudes toward the majority culture/congruence (measured as perceived similarity of the native and majority cultures on a scale of four levels)

- Ethnic background (measured as ethnic background of four grandparents)

- Ethnic identity (measured as self-identification-Russian, Estonian, other)

In this research, social dominance was examined through the Russianspeaking respondents' perceptions of how Estonians view the Russian speakers (as superior, equal, or inferior), and enclosure was considered as existing contact or wish for contact (on a four-point scale) with the majority population. Integration strategy was investigated by actualized integration, that is, by citizenship and second-language proficiency. Citizenship was measured by selection among the options of Russian, Estonian, and "other," and Estonian language proficiency was determined by self-categorization on a five-point scale. Length of residence (in years) was used as a variable instead of length of intended residence because of extremely low back migration of non-Estonians after the mid 1990s (Kirch 2001). Attitude toward the first language was measured as perceived importance of the Russian language in the future in Estonian society, indicated by a ranking order (1-5). Attitude toward the second language was measured by a perceived value of the Estonian language (on a scale of four levels). Attitude toward the native culture was measured by having respondents indicate their perception of the importance of Russian culture maintenance (on a four-point scale). In this research, the variable attitudes toward the majority culture was fused with congruence, or perceived similarity of Estonian and Russian cultures, and it was measured on a four-point scale. Ethnic background was determined by the origin of four grandparents, and ethnic identity by the options of Russian, Estonian, and "other."

A total of 445 questionnaires were distributed through teachers to students, who took them home to their parents and later returned the completed surveys to their teachers. Altogether 346 were completed and returned, for an overall response rate of 78 percent. Table 1 shows the sample sizes by town and by school type, with the response rates given in parentheses. Russianlanguage schools are typically described as more regulating and controlling than Estonian-language and bilingual schools (Vihalemm 1998), which might explain the higher response rates of Russian over Estonian schools. Many students in the Estonian school in Narva were sick during the research period, which may explain that school's low response rate (54 percent). In addition, 
LANGUAGE OF INSTRUCTION FOR RUSSIAN-SPEAKING CHILDREN IN ESTONIA

TABLE 1

Sample Size by Town and School Type (Response Rates in Parentheses)

\begin{tabular}{llcrr}
\hline & \multicolumn{3}{c}{ School Type } & \\
\cline { 2 - 4 } Town & Estonian & Russian & Bilingual & Total \\
\hline Tallinn & $59(63 \%)$ & $42(93 \%)$ & $20(83 \%)$ & $121(74 \%)$ \\
Tartu & $19(83 \%)$ & $41(79 \%)$ & $49(82 \%)$ & $109(81 \%)$ \\
Narva & $20(54 \%)$ & $45(82 \%)$ & $51(93 \%)$ & $116(79 \%)$ \\
\multicolumn{1}{c}{ Total } & $98(64 \%)$ & $128(84 \%)$ & $120(86 \%)$ & $346(78 \%)$ \\
\hline
\end{tabular}

this particular school has been a regular site for research, because it is the only Estonian-speaking school in the town-another factor which may have lowered the parental response rate.

\section{Data Analysis}

The 11 variables originally theorized to influence parental choice is a large number compared to the sample size of 346 respondents; thus the multiway contingency table showed lack of data in many cells, and the factors could not be examined in a single model. A screening process was needed, so bivariate analyses were conducted to cull down the list of "significant" variables (using .05 as the significance level for chi-square). Several explanatory variables were dealt with, and further limitation occurred through grouping the factors and thus screening for redundancies (Ramsey and Schafer 1997). Both theoretical and statistical elements were involved as the variables were grouped into meaningful categories by general themes or similarities based on the theoretical construct. The themes were language, culture, and ethnicity. The interaction of variables was tested to determine if any of the effects would be moderated or eliminated after adjusting for other variables. Polytomous logistic regression was employed to examine the grouped models of variables.

At the final stage of the analysis, the remaining significant variables were modeled together by polytomous logistic regression, because the response variable-choice between Russian-language schools, Estonian-language schools, and bilingual programs - was a categorical variable with three levels. The regression coefficients are interpreted as log-odds ratios. Choice of a Russian school was used as a reference category in modeling the odds; that is, the models were based on the odds of parents choosing a bilingual program over a Russian school or an Estonian school over a Russian school.

This process helped in recognizing redundancies and identifying central variables. However, the screening process and the special characteristics of the surveyed population might have eliminated relevant variables that should be included in research examining choice of language of instruction further in other geographic contexts. 
KEMPPAINEN, FERRIN, HITE, AND HILTON

TABLE 2

Demographics of Respondents $(n=346)$

\begin{tabular}{|c|c|c|}
\hline Demographic & Categories & Percentage \\
\hline Age & 38 years (average) & \\
\hline \multirow[t]{2}{*}{ Gender } & Female & 81 \\
\hline & Male & 19 \\
\hline \multirow[t]{3}{*}{ Education } & Basic & 6 \\
\hline & High school and vocational & 66 \\
\hline & College & 28 \\
\hline \multirow[t]{6}{*}{ Occupation } & Professional/managerial & 38 \\
\hline & Technical, sales & 21 \\
\hline & Service sector & 9 \\
\hline & Production & 19 \\
\hline & Operators, fabricators & 11 \\
\hline & Unemployed & 1.5 \\
\hline \multirow[t]{4}{*}{ Income } & Under EEK 30,000 & 12 \\
\hline & EEK 30,000-59,999 & 27 \\
\hline & EEK $60,000-120,000$ & 24 \\
\hline & Over EEK 120,000 & 5 \\
\hline \multirow[t]{3}{*}{ Length of residence } & Under 15 years & 6 \\
\hline & $15-30$ years & 35 \\
\hline & Over 30 years & 58 \\
\hline \multirow[t]{3}{*}{ Citizenship } & Russian & 12 \\
\hline & Estonian & 63 \\
\hline & Other & 24 \\
\hline \multirow[t]{5}{*}{ Estonian fluency } & None & 24 \\
\hline & Some & 34 \\
\hline & Fair & 18 \\
\hline & Good & 16 \\
\hline & Excellent & 8 \\
\hline \multirow[t]{8}{*}{ Ethnic background } & No Russian & 19 \\
\hline & One-quarter Russian & 5 \\
\hline & One-half Russian & 21 \\
\hline & Three-quarters Russian & 16 \\
\hline & All Russian & 38 \\
\hline & One-quarter Estonian & 10 \\
\hline & One-half to all Estonian & 13 \\
\hline & One-half to all other background & 22 \\
\hline \multirow[t]{3}{*}{ Ethnic identity } & Russian & 81 \\
\hline & Estonian & 7 \\
\hline & Other & 12 \\
\hline
\end{tabular}

\section{Results}

\section{Participant Demographics}

As described in table 2, one-third of the parents did not disclose their family income. Most of those who did disclose indicated annual incomes between EEK (Estonian kroons) 30,000 and 120,000 (US\$1,765-\$7,058), while gross domestic product and gross national income per capita in Estonia was $\$ 4,381$ in 2001 (ESA Statistikaamet 2003) $;^{15}$ only a small percentage had incomes above EEK 120,000. Over half the respondents had been born in Estonia or had lived there for more than 30 years; 43 percent had been born

\footnotetext{
${ }^{15}$ Using the Bank of Estonia currency rates calculator found at http://quote.ibs.ee/valuutad .cgi?date $=01.12 .2001$.
} 
outside Estonia. Nearly two-thirds of respondents had Estonian citizenship (63 percent). Although all the respondents were Russian speakers, one-fifth were not of Russian ethnic background (most were Ukrainian, Belarusian, Estonian, Finnish/Karelian, or Polish), and slightly less than 40 percent were fully Russian. Nearly one-fourth of these Russian-speaking respondents had some Estonian ethnic background. The category of "other," which included one-fifth of the respondents, refers to ethnic background other than Russian or Estonian. Despite their diverse ethnic backgrounds, 81 percent classified themselves with Russian identity: only 7 percent classified themselves with Estonian identity, and 12 percent categorized themselves as having some other ethnic identity. Table 2 presents the demographic profile of the respondents.

In describing the respondents, it is important to include their perceptions of ethnic relations and of culture and language attitudes. A significant 83 percent of the respondents think that Russians are considered inferior by Estonians. Only 23 percent of responding parents have contact with Estonian speakers or strongly wish for contact, 57 percent wish for contact, and 19 percent do not particularly wish for contact. Attitudes toward the first language vary, from seeing Russian as the most or second most important language in Estonia (39 percent) to seeing Russian as in third to fifth place (45 percent); 16 percent of the Russian speakers surveyed did not consider Russian to have any place among the languages important to the future of Estonia. Attitudes toward the second language vary from highly or very highly valuing Estonian (68 percent total) to not at all or only slightly valuing Estonian (32 percent). Russian speakers find maintaining Russian culture either important (84 percent) or very important (16 percent). And 74 percent of the parents perceived Estonian and Russian cultures to be dissimilar or very dissimilar.

Sociocultural Variables

In the bivariate analyses all but two of the variables, length of residence and cultural congruence, were significantly related to choice of language of instruction. ${ }^{16}$ There was little variation among respondents in length of residence (respondents tended to have lived in Estonia for a fairly long time) and cultural congruence (Russian speakers were able to cope in their daily activities using the Russian language), and this likely impacted the nonsignificant results. In the grouped analyses three more variables failed to show significance: citizenship, social dominance, and perceived importance of Russian language.

With limitations resulting from a small number of responses compared to a large number of variables, the remaining variables (fluency in Estonian, perceived value of Estonian language, perceived importance of Russian culture maintenance, ethnicity, ethnic identity, contact/wish for contact) could

\footnotetext{
${ }^{16}$ Table A1 in the appendix presents results of bivariate analysis of sociocultural variables and the dependent variable, parental choice of language of instruction for their child, by type of school.
} 
KEMPPAINEN, FERRIN, HITE, AND HILTON

TABLE 3

Final Model of Variables Related to Choice of Language of Instruction

\begin{tabular}{|c|c|c|c|c|c|}
\hline Term & Log Odds Ratio & $\mathrm{SE}$ & $X^{2}$ & $p$-value & Odds Ratio \\
\hline \multicolumn{6}{|l|}{$\begin{array}{l}\text { Significant variables explaining choice of } \\
\text { language of instruction/bilingual } \\
\text { school: }\end{array}$} \\
\hline $\begin{array}{l}\text { Estonian fluency (from some to } \\
\text { excellent) }\end{array}$ & -2.04 & .30 & .45 & .50 & .82 \\
\hline Ethnicity (other) & -.10 & .37 & .07 & .79 & .91 \\
\hline Ethnicity ( $50 \%$ or more Estonian) & .61 & .54 & 1.29 & .26 & 1.85 \\
\hline Ethnicity (25\% Estonian) & .83 & .53 & 2.44 & .12 & 2.30 \\
\hline Value of Estonian (high/very high) & .63 & .29 & 4.81 & .03 & 1.87 \\
\hline $\begin{array}{l}\text { Russian culture maintenance (very } \\
\text { important) }\end{array}$ & -.12 & .43 & .07 & .79 & .89 \\
\hline $\begin{array}{l}\text { Russian culture maintenance } \\
\text { (important) }\end{array}$ & .32 & .34 & .86 & .35 & 1.37 \\
\hline \multicolumn{6}{|l|}{$\begin{array}{l}\text { Significant variables explaining choice of } \\
\text { language of instruction/Estonian } \\
\text { school: }\end{array}$} \\
\hline Estonian fluency (some to excellent) & .97 & .46 & 4.50 & .03 & 2.64 \\
\hline Ethnicity (other) & -.01 & .42 & .00 & .97 & .99 \\
\hline Ethnicity ( $50 \%$ or more Estonian) & 1.73 & .52 & 10.94 & .0009 & 5.65 \\
\hline Ethnicity (25\% Estonian) & 1.47 & .56 & 6.87 & .008 & 4.37 \\
\hline Value of Estonian (high/very high) & 2.22 & .45 & 24.48 & .0001 & 9.18 \\
\hline $\begin{array}{l}\text { Russian culture maintenance (very } \\
\text { important) }\end{array}$ & -1.20 & .53 & 5.11 & .02 & .30 \\
\hline $\begin{array}{l}\text { Russian culture maintenance } \\
\text { (important) }\end{array}$ & .33 & .37 & .79 & .38 & .72 \\
\hline
\end{tabular}

not be analyzed together but first had to be analyzed in two sets of five variables. ${ }^{17}$ Ethnic identity and contact/wish for contact were not found to be significant in this stage of the analysis. All other variables, being significantly related to choice of language of instruction $(p \leq .05)$, were included in the final analysis. Table 3 presents the results of the final model, in which the remaining significant variables were combined and analyzed together.

In the final model with four variables (fluency in Estonian, ethnicity, perceived value of Estonian language, and perceived importance of Russian culture maintenance), only the perceived value of Estonian language was significant in explaining the choice of a bilingual program over a Russianlanguage school. However, all these variables were significant in explaining the choice of an Estonian over a Russian-language school. The perceived value of Estonian language had the strongest relation to the choice of an Estonian-language school, with the odds ratio of 9.18. Thus, the likelihood

\footnotetext{
${ }^{17}$ Initially, the variables fluency in Estonian; perceived value of Estonian language; and perceived importance of Russian culture maintenance, ethnicity, and ethnic identity were tested together, leaving out contact/wish for contact. In this analysis, all other variables remained significant except for identity. In the second round, fluency in Estonian, perceived value of Estonian language, perceived importance of Russian culture maintenance, ethnicity, and contact/wish for contact were tested together, leaving out ethnic identity. In this analysis all other variables remained significant except for wish for contact. Although perceived importance of Russian culture maintenance was at the borderline (.05), it was included in the final model.
} 
of choosing an Estonian school over a Russian school was nine times higher for parents who valued the Estonian language highly or very highly in comparison to those who valued it only slightly or not at all. The likelihood of choosing a bilingual program over a Russian school was nearly twice as high for parents who valued Estonian highly or very highly compared to parents who valued Estonian language only slightly or not at all. It appears that to be motivated to have one's children learn a second language, one has to perceive the language as a desirable or necessary competence.

Ethnicity was a significant variable explaining the choice of an Estonian over a Russian-language school, with the odds ratio of 5.65. Parents with at least 50 percent Estonian background were five and a half times more likely to choose Estonian schools over Russian schools than those with mostly Russian and no Estonian background. Even those with 25 percent Estonian background were four times as likely to choose Estonian schools as parents without Estonian background. The results indicate that the ethnic backgrounds of individuals within a minority group influence the language behavior of these individuals, such as choice of language of instruction for their children.

Perceived importance of Russian culture maintenance was also significant in explaining choice of language of instruction. Parents who ascribed a high level of importance to maintaining Russian culture were one-third less likely to choose an Estonian school over a Russian school compared to parents who did not perceive maintaining the Russian culture to be very important.

The fourth significant variable in explaining choice of language of instruction was parents' reported fluency in Estonian, with the odds ratio of 2.64. Parents with at least some level of fluency in Estonian were two and a half times more likely to choose Estonian schools than parents not fluent in the Estonian language. Thus, in choosing a school language for one's child, parents perceive their own proficiency in the second language as critical. ${ }^{18}$

\section{Discussion}

This research investigated the association of several sociocultural variables with parental choice of language of instruction. Because the choice of language of instruction is not widely explored in theoretical terms, this research

\footnotetext{
${ }^{18}$ In addition, this study tested statistically the language and culture orientation categories identified in the qualitative study by Kemppainen et al. (2004) in which the categories were based on given orientation statements. Table A2 in the appendix displays the results of the bivariate analysis of the selfassigned culture and language orientation categories and their association to different levels of choice. In this testing, Russian schools were used as the reference group, and the parental orientation categories were compared to the parents with Russian orientation. Although no significant association was found between the categories of parental orientations and the choice of bilingual programs over Russian schools, the multicultural, bicultural, and Estonian orientations were significantly associated with the choice of Estonian schools over Russian schools $(p=.0001, .004$, and .0001 , respectively), meaning that if parents associate themselves either with many languages and cultures, with both Estonian and Russian languages and cultures, or with Estonian language and culture, they are more likely to choose Estonian-language schools than parents who associate themselves with Russian language and culture.
} 
and its findings contribute significantly to the body of literature on this phenomenon. The variables used to build the initial model were drawn mostly from literature on second-language acquisition that could be applied to the context of choosing language of instruction as well.

The initial model was informed by Schumann's $(1978,1986)$ acculturation theory of second-language acquisition and a qualitative study conducted by Kemppainen and colleagues (2004) that focused on identifying preliminary variables related to parental choice of language of instruction. The results of the research revealed language variables related to both integration and attitudes. Ethnic background and other culture variables were also shown to be important in building a model of choice of language of instruction.

Parents' own second-language proficiency was found to influence the type of school they chose for their children, supporting the importance of integration strategy in language behavior, as suggested by Schumann (1978, 1986). The higher parents' proficiency in Estonian, the more likely they were to choose Estonian schools over Russian schools. However, this association was not observed in the choice of bilingual programs over Russian schools. In Estonian-speaking schools Estonian is the medium of instruction, whereas the bilingual programs instruct in both Estonian and Russian.

Ülle Rannut's (2005) research similarly indicates that second-language proficiency is connected with the choice of language of instruction among Russian-speaking parents. According to her research, in Tallinn (in which nearly half the inhabitants are Russian speakers) parents whose children attend Estonian-language schools all spoke at least some Estonian, whereas 20 percent of parents with children in Russian-language schools reported that they knew no Estonian. In Russian-language-dominated Eastern Estonia only 6 percent of parents with children in Estonian-language schools did not speak Estonian at all, while nearly 71 percent of parents with children in Russian-speaking schools did not speak any Estonian.

The results of both this research and Rannut's follow-up study strongly suggest that parents' fluency in the second language influences their desire to send their children to a school that uses the second language as the sole medium of instruction. However, in putting their children in bilingual programs, parents may not have to consider such issues. For a language-ofeducation policy, this finding may have important implications. Parents' lack of second-language proficiency may raise serious educational concerns, such as, for example, their inability to help with homework or to interact fully in the school community. The results indicate an important difference between bilingual programs and education in the second language, highlighting the attraction of bilingual programs to parents who speak only their native language.

Attitudes toward the native culture also appear to be important in parents' choice of language of instruction for their children's schooling. The parents 
who consider Russian culture maintenance very important tend to send their children to Russian-language schools. Choosing education in the family's first language reflects the parents' desire to maintain the family culture. The findings of the current research support the findings by Kemppainen and colleagues (2004), who demonstrated that parents with different culture and language orientations choose language of instruction differently.

Discussion on motivation to learn a language often emphasizes two motives mentioned by Gardner and Lambert (1972): instrumental and integrative. In this research, we found evidence that a nonintegrative or cultural motive-that is, desire to maintain ones' own culture-affects choice of language of instruction children's schooling. Parents may send their children to a school providing instruction in the first language as a way of passing on the native culture in addition to a sense of belonging to the extended family and its origins. As Fernand de Varennes (1995-96, 107) put it, "language is often central to feelings of community and culture, of tradition and belonging." Cultural maintenance may be perceived as an important foundation for cultural identity, which may impact success in school (Cummins 1982) as well as in the cultural community. This relationship should not be ignored in language-of-instruction policies and practices.

Although language use and language-based school choice are complex phenomena involving many factors, and some claim that ethnicity may not be the primary factor in language use (Ozolins 1996), this research indicates that parents' ethnic background significantly influences their language of instruction preferences for their children. Ethnicity has deep meaning for many families; however, the significance of ethnic affiliation has not been given weight in language policy discussion. Additionally, the results of this study demonstrate the complexity of ethnic composition among a minority group sharing a language. Unfortunately, language minorities are typically perceived as homogeneous groups with the same ethnic backgrounds, identities, interests, and needs. For example, the Spanish-speaking students in the United Sates are often perceived as one group without careful attention to the many special circumstances and affiliations (e.g., Californian, Cuban, Mexican, Puerto Rican) of the student. This oversimplification is damaging to educational practice as well as cultural dispositions. This research suggests that to address the needs of minority language students, the one-size-fits-all approach is not adequate. Even though the population may be speaking the same language (e.g., Russian), families may differ with respect to their ethnic background (including having grandparents with a mixture of different national origins).

It is not surprising that attitude toward the second language (the perceived value of the second language) is the variable in the model that has the strongest impact on parents' choice of language of instruction for their children. Schumann's model $(1978,1986)$ suggests intergroup attitudes as a 
powerful influence for second-language learning. In addition, Ülle Rannut's (2005) follow-up research, which tested some of the findings of the present study, indicates that valuing the second language correlates with choosing to educate one's children in the second language. According to her research in linguistically segregated Tallinn, 33 percent of parents whose children attend Estonian-language schools consider the Estonian language to be very important, while none of the parents who had placed their children in Russian-language schools value Estonian as highly. Although being able to communicate in the dominant language of a nation appears critical for all students, the question arises whether exclusive language policies observed in many parts of the world contribute to valuing the nationally dominant language or whether policies allowing some choices are more successful in improving language dispositions.

Estonia faces the challenge of encouraging second-language learning for all Russian-speaking children in today's language environment while simultaneously supporting their native culture maintenance. Language choice is a multifaceted phenomenon not amenable to simple solutions. However, Estonian language-of-instruction policy, allowing schooling alternatives for Russian speakers' children, can provide for the needs of families with differing lifestyles and orientations.

\section{Conclusions}

This study identified several relevant variables related to choice of language of instruction, a topic where research is nearly nonexistent. It was hypothesized that Estonian citizenship would predict choice of Estonian schools; however, citizenship was not found to be significantly related to language-of-instruction choice when controlling for ethnicity and ethnic identity. Additionally, the perceived importance of Russian language was not found to be significantly related to choice of Russian-language schools, when other language-related variables (such as perceptions of Estonian fluency and Estonian value) were included in the equation. ${ }^{19}$ And our measure of social dominance was not found to be significantly related to language-of-instruction choice when adjusted for a set of culture-related variables (such as Russian culture maintenance), although it was expected that perceptions of equality with Estonians would predict choice of Estonian-language schools.

Of the variables that did not have a significant relationship with languageof-instruction choice in the final modeling, ethnic identity clearly exhibited

\footnotetext{
${ }^{19}$ Perhaps the wording of the variable concerning importance of Russian language ("the importance of Russian language in Estonian society in the future") and the variable of Estonian value concerned two sides of the same issue, suggesting that someone who did not see a use for Russian valued Estonian, and therefore the variables were highly correlated. If the question regarding the variable had been formulated to reflect the respondents' personal views on the importance of the Russian language, the variable might have remained significant.
} 
redundancy with ethnicity and also with native culture maintenance. Contact/ wish for contact with Estonians was hypothesized to be related with choice of Estonian schools. The effect of this variable, however, was apparently diminished by controlling for other sociocultural variables (e.g., Estonian fluency and Estonian values).

Although sociocultural variables are widely recognized as critical in second-language acquisition (Cummins 1982, 2000; Krashen 1996), they are not sufficiently incorporated into language-of-instruction policies in many countries. As suggested by this research, understanding the language preferences of parents and children is critical in forming language-of-instruction policies. Further research is needed to investigate whether parental sociocultural and attitudinal variables transfer across contexts and predict choice of language of instruction more universally.

Estonian policies and options regarding Russian speakers, like those for Swedish speakers in Finland, offer some language-of-instruction choices for a minority group that speaks its own native language. Both of these populations, however, represent languages groups that were formerly dominant. Families of other language minority cultures (e.g., Turks in Germany and Latinos in the United States) also need options for language of instruction that respond to their preferences and needs.

Parents' concerns relating to language and culture may well be more pronounced under circumstances where educational language policies are forceful, as in the United States and Germany. In such places, majoritarian processes are widely utilized in determining language-of-instruction policies and immigrant issues. Although research in education and the social sciences tends to support bilingualism in the U.S. school system (e.g., Ovando and Collier 1998; Krashen and McField 2005), the trend has been to discourage it-as evidenced in banning of bilingual education in some states. Conversely, in Germany the rising trend of openly discussing language of instruction at the political level, including support for multilingualism (Beck 2003; Brüntink 2003), is encouraging.

Appendix

TABLE A1

Sociocultural Variables and Their Significance Related to Choice of Language of Instruction

\begin{tabular}{llccc}
\hline Variable & \multicolumn{1}{c}{ Levels of Variable } & DF & $\chi^{2}$ & $p$-value \\
\hline Social dominance & Inferior, equal (superior)* & 2 & 10.51 & .005 \\
Contact/wish for contact with Estonians & Have contact/strongly wish, wish, \\
& do not wish particularly (do & & & \\
& not wish at all)* & 4 & 19.50 & .0006 \\
& Russian, Estonian, other & 4 & 20.81 & .00003 \\
Citizenship & None, some/fair, good/excellent & 4 & 24.67 & .0001 \\
Estonian fluency & 0-15 years, 15-30 years, 30+ & & & \\
Length of residence & years & 4 & 3.82 & .43
\end{tabular}


TABLE A1 (Continued)

\begin{tabular}{|c|c|c|c|c|}
\hline Variable & Levels of Variable & $\mathrm{DF}$ & $\chi^{2}$ & $p$-value \\
\hline Importance of Russian language & $1-2,3-5$, not listed & 4 & 14.69 & .005 \\
\hline Estonian language value & Not/slightly, high/very high & 2 & 45.00 & .0001 \\
\hline Russian culture maintenance & $\begin{array}{l}\text { Very unimportant/unimportant/ } \\
\text { important, very important }\end{array}$ & 2 & 6.15 & .046 \\
\hline Cultural similarity & $\begin{array}{l}\text { Very dissimilar, dissimilar, similar } \\
\quad \text { (very similar)* }\end{array}$ & 4 & 4.02 & .40 \\
\hline Ethnic background (mostly Russian) & $0 \%, 25 \%, 50 \%, 75 \%, 100 \%$ & 8 & 30.57 & .0002 \\
\hline Ethnic background (mostly Estonian) & $0 \%, 25 \%, 50 \%-100 \%$ & 4 & 29.23 & .0001 \\
\hline Ethnic background (mostly other) & $0 \%, 25 \%, 50 \%, 75 \%, 100 \%$ & 8 & 8.22 & .41 \\
\hline Ethnic identity & Russian, Estonian, other & 4 & 47.80 & .0001 \\
\hline
\end{tabular}

*The variable levels in parentheses were omitted before the analysis because there were fewer than six responses in them.

TABLE A2

Association of the Choice of Language of Instruction with

Parental Culture/Language Orientation Categories

\begin{tabular}{lrrr}
\hline Orientation & SE & $\chi^{2}$ & $p$-value \\
\hline Choice of bilingual program over Russian school: & & \\
$\quad$ Multicultural orientation & .57 & 2.20 & .14 \\
$\quad$ Bicultural orientation & .33 & 2.33 & .13 \\
$\quad$ Estonian orientation & .57 & .71 & .40 \\
Choice of Estonian school over Russian school: & & .64 & .0001 \\
$\quad$ Multicultural orientation & .48 & .37 & .004 \\
$\quad$ Bicultural orientation & .61 & 18.94 & .0001 \\
$\quad$ Estonian orientation & & & \\
\hline
\end{tabular}

\section{References}

August, Diane, and Kenji Hakuta, eds. 1997. Improving Schooling for Language-Minority Children: A Research Agenda. Washington, DC: National Academy Press.

Beck, Marieluise. 2003. "Grusswort" (Greeting). In Förderung von Migranten und Migrantinnen im Elementar- und Primabereich (Support for immigrants in elementary and primary areas). Documentation from Berlin symposium, March 7, 2003. Berlin: Bundersregierung für Migration, Flüchtlinge und Integration (Federal administration for immigration, refugees, and integration).

Brüntink, Corinna. 2003. "Bildungspolitische Aspekte der Förderung von Kindern and Jugendlichen mit Migrationshintergrund aus bildungspolitischer Sicht" (Educational politics aspects of support for children and adolescents with immigrant background from a view of educational politics). In Förderung von Migranten und Migrantinnen im Elementar- und Primabereich (Support for immigrants in elementary and primary areas). Documentation from Berlin symposium, March 7, 2003. Berlin: Bundersregierung für Migration, Flüchtlinge und Integration (Federal administration for immigration, refugees, and integration).

Capotorti, Francesco. 1977. "Study on the Rights of Persons Belonging to Ethnic, Religious and Linguistic Minorities.” United Nations document E/CN.4/Sub.2/ 384/Add.1-7. United Nations, New York. 
Cummins, Jim. 1982. "The Role of Primary Language Development in Promoting Educational Success for Language Minority Students." In California State Department of Education, Office of Bilingual Bicultural Education, Schooling and Language Minority Students: A Theoretical Framework. Los Angeles: California State University, Evaluation, Dissemination and Assessment Center.

Cummins, Jim. 2000. "Beyond Adversarial Discourse: Searching for Common Ground in the Education of Bilingual Students." In The Politics of Multicultural and Bilingual Education: Students and Teachers Caught in the Cross Fire, ed. C. J. Ovando and P. McLaren. Boston: McGraw-Hill.

de Varennes, Fernand. 1995-96. "The Protection of Linguistic Minorities in Europe and Human Rights: Possible Solutions to Ethnic Conflicts?” Columbia Journal of European Law 2 (Fall/Winter): 107-43.

ESA Statistikaamet. 2003. Database, http://pub.stat.ee/px-web.2001/I_Databas/ Economy/Economy.asp: main national accounts indicators; gross domestic product and gross national income (gross national product) per capita, kroons, euros, US dollars; gross national product at current prices per capita, US dollars.

ESA Statistikaamet. 2005. Database, http://pub.stat.ee/px-web.2001/Database/ Rahvaloendus/Rahvaloendus.asp; path: Rahvus. Emakeel. Võõrkeelteoskus (Nationality. First language. Knowledge of foreign languages); Rahvastik elukoha ja rahvuse järgi (Population according to residence and nationality); Rahvastik rahvuse, emakeele ja kodakondsuse järgi (Population according to nationality, first language and citizenship).

Estonian Ministry of Education. 1997. Education in Estonia: Present Situation and Developments, July 1996. Tallinn: Estonian Ministry of Education.

Fowler, Floyd J. 1993. Survey Research Methods. Vol. 1. Newbury Park, CA: Sage.

Gardner, Robert C., and Wallace E. Lambert. 1972. Attitudes and Motivation in SecondLanguage Learning. Rowley, MA: Newbury House.

Glenn, Charles L. 1997. "What Does the National Research Council Study Tell Us about Educating Language Minority Children?” READ Perspectives 4 (Fall): 66-95.

Gogolin, Ingrid. 2003. "Gleiche Bildungschancen für Kinder mit Migrationshintergrund-möglich auch in Deutschland?” (Equal educational opportunities for children with immigrant background-is it possible in Germany as well?). In Förderung von Migranten und Migrantinnen im Elementar- und Primabereich (Support for immigrants in elementary and primary areas). Documentation from Berlin symposium, March 7, 2003. Berlin: Bundersregierung für Migration, Flüchtlinge und Integration (Federal administration for immigration, refugees, and integration).

Hebenstreit-Müller, Sabine. 2003. "Begrüssung” (Welcoming address). In Förderung von Migranten und Migrantinnen im Elementar- und Primabereich (Support for immigrants in elementary and primary areas). Documentation from Berlin symposium, March 7, 2003. Berlin: Bundersregierung für Migration, Flüchtlinge und Integration (Federal administration for immigration, refugees, and integration).

Issakov, Sergei. 1999. "Venelased" (The Russians). In Eesti rahvaste raamat: Rahvusvahemused, -rumad ja-killud (Estonian nationalities book: National minorities, groups, and fragments), ed. J. Viikberg. Tallinn: Eesti Entüklopeediakirjastus.

Joppke, Christian. 1996. "Multiculturalism and Immigration: A Comparison of 
the United States, Germany, and Great Britain.” Theory and Society 25 (August). http://www.springerlink.com/content/1800871577132122/.

Kalter, Frank, and Nadia Granato. 2002. "Ethnic Minorities' Education and Occupational Attainment: The Case of Germany." Working Paper no. 58, Mannheimer Zentrum für Europäische Sozialforschung, Mannheim. http://www.mzes .uni-mannheim.de/publications/wp/wp-58.pdf.

Katus, Kalev, Marek Kupiszewski, Philip Rees, Luule Sakkeus, Anne Herm, and David Powell. 1998. Internal Migration and Regional Population Dynamics in Europe: Estonia Case Study. Working Paper no. 98/14, Estonian Interuniversity Population Research Center, Tallinn. http://www.geog.leeds.ac.uk/wpapers/98-14.pdf.

$\rightarrow$ Kemppainen, Raija, and Scott E. Ferrin. 2002. "Parental Choice and Language-ofInstruction Policies and Practices in Estonia." Education and Urban Society 35 (1): 76-99.

$\rightarrow$ Kemppainen, Raija, Scott E. Ferrin, Carol J. Ward, and Julie M. Hite. 2004. "One Should Not Forget One's Mother Tongue: Russian-Speaking Parents' Choice of Language of Instruction in Estonia." Bilingual Research Journal 28 (2): 207-29.

Kionka, Riina, and Raivo Vetik. 1996. "Estonia and the Estonians." In The Nationalities Question in the Post-Soviet States, ed. G. Smith. London: Longman.

Kirch, Aksel. 1999. "Eesti etniline koosseis" (Estonian ethnic composition). In Eesti rahvaste raamat: Rahvusvahemused, -rumad ja-killud (Estonian nationalities book: National minorities, groups, and fragments), ed. J. Viikberg. Tallinn: Eesti Entüklopeediakirjastus.

Kirch, Aksel. 2001. "Estonian Report on Russian Minority." Institute for European Studies, Tallin. http://www.ies.ee/kirchrus.pdf.

Kirch, Marika, Aksel Kirch, Ilvi Rimm, and Tarmo Tuisk. 1997. "Integration Processes in Estonia, 1993-1996." In The Integration of Non-Estonians into Estonian Society: History, Problems, and Trends, ed. A. Kirch. Tallinn: Estonian Academy.

Krashen, Stephen D. 1996. Under Attack: The Case against Bilingual Education. Culver City, CA: Language Education Associates.

Krashen, Stephen, and Grace McField. 2005. "What Works: Reviewing the Latest Evidence on Bilingual Education." National Association of Bilingual Educators, Language Learner (November/December). http://users.rcn.com/crawj/langpol/ Krashen-McField.pdf.

Kunnas, Kaja. 2004. "Kolmannes Viron venäläisnuorist ei halua opiskella viroa" (One-third of Russian youth in Estonia do not want to study Estonian). Helsingin Sanomat, October 5.

Lainio, Jarmo. 2001. "The Protection and Rejection of Minority and Majority Languages in the Swedish School System." In Managing Multilingualism in a European Nation-State: Challenges for Sweden, ed. S. Boyd and L. Huss, Clevedon: Multilingual Matters.

Laitin, David D. 1996. "Language and Nationalism in the Post-Soviet Republics." Post-Soviet Affairs 12 (1): 4-24.

Landry, Rodrique, and Réal Allard. 1985. "Choix de la langue d'enseignement: Une analyse chez des parents francophones en milieu bilingue soustractif" (Choice of the language of instruction: An analysis of Francophone parents in a subtractive bilingual milieu). Canadian Modern Language Review 41 (3): 480-500.

Language Immersion Centre. 2006a. "Major Program Achievements." http:// 
www.kke.ee/index.php?lang = eng\&pages_ID $=29 \&$ menus_ID $=13 \&$ active_link_ $\mathrm{ID}=86 \& \mathrm{mar}=0$.

Language Immersion Centre. 2006b. “Language Immersion.” http://www.kke.ee/ index.php?lang = eng\&pages_ID = 174\&menus_ID = 1\&active_link_I.

Language Immersion Centre. 2006c. "Kindergartens and Schools." http://www .kke.ee/index.php?lang $=$ eng\&menus_ID $=6 \&$ pages_ID $=6 \&$ mark $=0$.

Mets, Elle. 2004. "Keel ja Ühiskond: Erakondade Suhtumine Keeleküsimusse.” In Eesti Keel: Voorkeelest teiseks Keeleks, ed. M. Rannut. Tallinn: Tallinn Pedagogical University.

Neuman, W. Lawrence. 1994. Social Research Methods: Qualitative and Quantitative Approaches. 2nd ed. Boston: Allyn \& Bacon.

Opetushallitus (Finnish National Board of Education). 2004. "Maahanmuuttajaoppilaiden perusopetukseen valmistava opetus ja perusopetus syyslukukaudella 2003" (Immigrant students' preparatory education to basic education and basic education in the fall semester of 2003). Report, National Board of Education, Finland, April 3.

Østergaard-Nielsen, Eva. 2003. Transnational Politics: Turks and Kurds in Germany. London: Routledge.

Ovando, Carlos J., and Virginia P. Collier. 1998. Bilingual and ESL Classrooms: Teaching in Multicultural Contexts. 2nd ed. Boston: McGraw-Hill.

$\rightarrow$ Ozolins, Uldis. 1996. "Language Policy and Political Reality." International Journal of the Sociology of Language 118:181-200.

Ozolins, Uldis. 2000. "Between Russian and European Hegemony: Current Language Policy in the Baltic States." In Language Policy and Language Issues in the Successor States of the Former USSR, ed. S. Wright. Clevedon: Multilingual Matters.

Pavelson, Marje. 2000. "Haridus ja haridustaotlused" (Education and aspirations for education). In Integration of Estonian Society: Monitoring 2000. Tallinn: Institute of International and Social Studies.

Pettai, Iris, and Ivi Proos. 1999. Kooliarendus: Kutse dialoogile (School progress: A call for dialogue). Vol. 4. Kool ja integrasioon: Integratsioon ja kool (School integration: Integration and school). Tallinn: Haridusministeerium Eesti Avatud Ühiskonna Institut.

Radzevich, Y. 2004. Minister of Education and Science, press release, April 30.

Ramsey, Fred, and Daniel W. Schafer. 1997. The Statistical Sleuth: A Course in Methods of Data Analysis. Belmont, CA: Duxbury Press.

Rannut, Mart. 1991. "Beyond Linguistic Policy: The Soviet Union versus Estonia." Roskilde University Center, Roskilde. ERIC Document Reproduction Service no. ED 352803.

Rannut, Mart. 2001. "Estonian Language Policy in the 1990s." In Tutkielmia vähemmistökielistä Jäämereltä Liivinrantaan: Vahemmistökielten tutkimus ja koulutusverkoston raportti (Research on minority languages from the Polar Sea to the shores of Livonia: A report by the research and education network on minority languages), ed. M. Mikkonen, H. Sulkala, and H. Mantila. Oulu: University of Oulu.

Rannut, Mart. 2004a. Language Planning in Estonia: Past and Present. Barcelona: Escarré International Centre for Ethnic Minorities and Nations.

Rannut, Mart. 2004b. "Language Policy in Estonia." Noves SL: Revista de Sociolin- 
güistica (Spring-Summer). http://www6.gencat.net/llengcat/noves/hm04prima vera-estiu/docs/rannut.pdf.

Rannut, Mart, and Ülle Rannut. 1995. "Bilingualism-a Step toward Monolingualism or Multiculturalism?” In Multilingualism for All, ed. T. Skutnabb-Kangas. Lisse: Swets \& Zeitlinger.

Rannut, Ülle. 2005. Keelekeskkonna mõju vene óppilaste eesti keele omandamisele ja integratsioonile Eestis (Impact of the language environment on integration and Estonian-language acquisition of Russian-speaking children in Estonia). Tallinn: TLÜ kirjastus.

Riiklik eksami-ja kvalifikatsioonikeskus. 2006. "Riigieksamite statistikaaruanneeg 77-02/2005: Eksamitulemuste statistika (õppekeel)" (Statistical report of national exams: Statistics of exam results [language of instruction]). http:// www.ekk.edu.ee/statistika/riigieksamid/gymnaasium/2005/yld/kaust/eg77_02 .html.

Schumann, John H. 1978. "The Acculturation Model for Second-Language Acquisition.” In Second-Language Acquisition and Foreign Language Teaching, ed. R. C. Gingras. Arlington, VA: Center for Applied Linguistics.

$\rightarrow$ Schumann, John H. 1986. "Research on the Acculturation Model for Second Language Acquisition." Journal of Multilingual and Multicultural Development 7 (5): 379-92.

Smith, David J. 1998. "Russia, Estonia and the Search for Stable Ethnopolitics." Journal of Baltic Studies 29 (1): 3-18.

Smith, Graham, Vivien Law, Andrew Wilson, Annette Bohr, and Edward Allworth. 1998. Nation-Building in the Post-Soviet Borderlands: The Politics of National Identities. Cambridge: Cambridge University Press.

Titma, Mikk, Nancy Brandon Tuma, and Brian D. Silver. 1998. "Winners and Losers in the Postcommunist Transition: New Evidence from Estonia." Post-Soviet Affairs 14 (2): 114-36.

Tuomela, V. (2001). "Tvåspråkig utveckling i skolåldern: En jämförelse av sverigefinska elever i tre undervisningsmodeller" (Bilingual development at school age: A comparison of Sweden Finns in three teaching models). Dissertation, University of Stockholm.

Vallens, Dagmara. 1995. "The Law of Aliens Controversy in the Baltic States." Review: International Commission of Jurists 54 (June): 1-28.

Vassiltshenko, Larissa, Tiia Pedastsaar, Maie Soll, Ulve Kala, and Silvia Kera. 1998. "Venekeelse kooli erinevate mudelitega seotud ootused ja kartused haritussubjektide seas" (Expectations and concerns regarding different models in Russianspeaking schools among educational actors). In Mitmekultuuriline Eesti: Väljakutse haridusele (Multicultural Estonia: A challenge for education), ed. M. Lauristin, S. Vare, T. Pedastsaar, and M. Pavelson. Tartu: Tartu Ülikool.

Veidemann, Andra. 1999. "Eesti rahvus- ja rahvastikupoliitika" (Estonian ethnicity and population politics). In Eesti rahvaste raamat: Rahvusvähemused, -rümad ja -killud (Estonian nationalities book: National minorities, groups, and fragments), ed. J. Viikberg. Tallinn: Eesti Entsüklopeediakirjastus.

$\rightarrow$ Vetik, R. 1993. "Ethnic Conflict and Accommodation in Post-Communist Estonia." Journal of Peace Research 30 (3): 271-80. 
Vetik, Raivo. 1999. Inter-ethnic Relations in Estonia, 1988-1998. Tampere: University of Finland.

Vihalemm, Triin. 1997. "Kodu materiaalsed ressursid ja vene noorte integratsiooni perspektiivid" (Family material resources and perspectives of Russian youth integration). In Vene noored Eestis: Sotsioloogilige mosaiik (Russian youth in Estonia: A sociological mosaic), ed. P. Järve. Tallinn: Avita.

Vihalemm, Triin. 1998. "Eesti kool kui vene laste võimalik sotsialiseerumiskeskond" (An Estonian school as a possible socializing milieu for Russian children). In Mitmekultuuriline Eesti: Väljakutse haridusele Väljanne (Multicultural Estonia: A challenge for education), ed. M. Lauristin, S. Vare, T. Pedastsaar, and M. Pavelson. Tartu: Tartu Ülikool.

Vihalemm, Triin, and M. Lauristin. 1999. Cultural Adjustment to the Changing Societal Environment: The Case of Russians in Estonia. Tartu: Tartu University Press. 